\title{
Cutaneous Lipomatous Neoplasm
}

National Cancer Institute

\section{Source}

National Cancer Institute. Cutaneous Lipomatous Neoplasm. NCI Thesaurus. Code C5566.

A benign or malignant adipose tissue neoplasm of the skin. 